\title{
Pretranslational Suppression of a Glucose Transporter Protein Causes Insulin Resistance in Adipocytes from Patients with Non-Insulin-dependent Diabetes Mellitus and Obesity
}

\author{
W. Timothy Garvey," Lidia Maianu, "Thomas P. Huecksteadt, ${ }^{*}$ Morris J. Bimbaum," Joseph M. Molina," \\ and Theodore P. Ciaraldi" \\ * Section of Endocrinology Indiana University School of Medicine and the Indianapolis Veterans Administration Medical Center \\ Indianapolis, Indiana 46202; ${ }^{\ddagger}$ University of Utah Medical Center, Salt Lake City, Utah 84108; ${ }^{\S}$ Harvard Medical School, \\ Boston, Massachusetts 02215; 'University of California San Diego School of Medicine and the San Diego \\ Veterans Administration Medical Center, San Diego, California 92161
}

\begin{abstract}
A major portion of insulin-mediated glucose uptake occurs via the translocation of GLUT 4 glucose transporter proteins from an intracellular depot to the plasma membrane. We have examined gene expression for the GLUT 4 transporter isoform in subcutaneous adipocytes, a classic insulin target cell, to better understand molecular mechanisms causing insulin resistance in non-insulin-dependent diabetes mellitus (NIDDM) and obesity. In subgroups of lean (body mass index [BMI] $=24 \pm 1$ ) and obese (BMI $=32 \pm 2)$ controls and in obese NIDDM (BMI $=35 \pm 2$ ) patients, the number of GLUT 4 glucose transporters was measured in total postnuclear and subcellular membrane fractions using specific antibodies on Western blots. Relative to lean controls, the cellular content of GLUT 4 was decreased $40 \%$ in obesity and $85 \%$ in NIDDM in total cellular membranes. In obesity, cellular depletion of GLUT 4 primarily involved low density microsomes (LDM), leaving fewer transporters available for insulin-mediated recruitment to the plasma membrane (PM). In NIDDM, loss of GLUT 4 was profound in all membrane subfractions, PM, LDM, as well as high density microsomes. These observations corresponded with decrements in maximally stimulated glucose transport rates in intact cells. To assess mechanisms responsible for depletion of GLUT 4, we quantitated levels of mRNA specifically hybridizing with human GLUT 4 cDNA on Northern blots. In obesity, GLUT 4 mRNA was decreased $36 \%$ compared with lean controls, and the level was well correlated $(r=+0.77)$ with the cellular content of GLUT 4 protein over a wide spectrum of body weight. GLUT $4 \mathrm{mRNA}$ in adipocytes from NIDDM patients was profoundly reduced by $86 \%$ compared with lean controls and by $78 \%$ relative to their weight-matched nondiabetic counterparts (whether expressed per RNA, per cell, or for the amount of CHO-B mRNA). Interestingly, GLUT 4 mRNA levels in patients with impaired glucose tolerance $(B M I=34 \pm 4)$ were decreased to the same level as in overt NIDDM.

We conclude that, in obesity, insulin resistance in adipocytes is due to depletion of GLUT 4 glucose transporters, and that the cellular content of GLUT 4 is determined by the level
\end{abstract}

Address correspondence to Dr. W. Timothy Garvey, Section of Endocrinology, VA Hospital 111-E, 1481 West 10th Street, Indianapolis, IN 46202.

Received for publication 22 August 1990 and in revised form 12 October 1990.

The Journal of Clinical Investigation, Inc.

Volume 87, March 1991, 1072-1081 of encoding mRNA over a wide range of body weight. In NIDDM, more profound insulin resistance is caused by a further reduction in GLUT 4 mRNA and protein than is attributable to obesity per se. Suppression of GLUT 4 mRNA is observed in patients with impaired glucose tolerance, and therefore, may occur early in the evolution of diabetes. Thus, pretranslational suppression of GLUT 4 transporter gene expression may be an important mechanism that produces and maintains cellular insulin resistance in NIDDM. (J. Clin. Invest. 1991. 87:1072-1081.) Key words: insulin resistance • glucose transporter • gene expression • adipocyte • non-insulin-dependent diabetes mellitus $\bullet$ obesity $\bullet$ impaired glucose tolerance - GLUT 4

\section{Introduction}

Insulin resistance is a major metabolic abnormality causing hyperglycemia in patients with type II non-insulin-dependent diabetes mellitus (NIDDM), ${ }^{1}$ and is primarily due to defects in target tissue that lie distal to insulin binding in the insulin action pathway $(1,2)$. Investigators have used isolated adipocytes $(3,4)$ and muscle explants $(5)$ to study insulin action at the cellular level, and have demonstrated impaired stimulation of the glucose transport system in these patients. In adipocytes, decreased basal and insulin-stimulated glucose transport rates found in vitro correlated well with the in vivo expression of the post-binding defect (6), which suggested that an important cellular abnormality in NIDDM lies intrinsic to the glucose transport effector system.

Insulin activates glucose transport in rat $(7,8)$ and human adipocytes $(9,10)$ via a rapid and reversible recruitment of glucose transport proteins from a large intracellular pool to the plasma membrane. In studies to determine the biochemical basis of insulin resistance, we previously demonstrated reduced cellular numbers of glucose transporters in NIDDM and obesity (10). In these studies, we used the cytochalasin B binding assay to quantitate glucose transporters in adipocyte membrane subfractions; this chemical affinity assay measures all facilitative glucose transporters and does not discriminate between individual transporter isoforms.

It has recently become clear that a family of glucose transporter genes exists with variable tissue-specific expression (see

1. Abbreviations used in this paper: BMI, body mass index; HDM, high density microsomal membrane; IGT, impaired glucose tolerance; LDM, low density microsomal membrane; NIDDM, non-insulin-dependent diabetes mellitus; PM, plasma membrane. 
reference 11 for review). GLUT 1 transporters (12-14) are present at the cell surface of basal adipocytes, and become enriched less than or equal to twofold in the plasma membrane following acute insulin stimulation and recruitment of GLUT 1 from the cell interior. This does not fully account for insulin's ability to stimulate glucose transport rates $\sim 5$-fold above basal in human adipocytes and by more than 10-fold in rat adipocytes. Also, GLUT 1 transporters are expressed at low levels in skeletal muscle, which is the most important tissue for insulin-mediated glucose disposal in vivo (15). For these reasons, the GLUT 1 isoform is not likely to mediate the major portion of insulin-stimulated glucose transport activity. GLUT $2(16,17)$ expression is restricted to liver, kidney, and pancreatic $\beta$ cells whereas GLUT 3 (18) is found ubiquitously in placenta, brain, kidney, and other tissues; however, neither of these latter isoforms is highly expressed in classic insulin target tissues (i.e., muscle and fat). More recently, GLUT 4 transporters have been cloned from both muscle $(19,20)$ and adipocyte $(21,22)$ cDNA libraries. This novel transporter isoform is expressed exclusively in fat and striated muscle, and the protein increases $\sim 10$-fold in rat adipocyte plasma membranes after acute insulin stimulation. Thus, GLUT 4 has characteristics of an "insulin-responsive" transporter that appears to predominate in facilitating insulin-mediated glucose uptake. We (23) and others (24-26) have shown that pretranslational suppression of GLUT 4 (but not GLUT 1) transporters in fat and muscle tissue causes insulin resistance in streptozotocin-treated diabetic rats. However, the role of individual glucose transporter isoforms in human disease, and which species account for cellular depletion of transporter proteins in NIDDM and obesity, have not been elucidated.

In human adipocytes, GLUT 4 is the predominant facilitative glucose transporter isoform, and appears to mediate the major portion of insulin-mediated glucose uptake (27). Therefore, in the current studies, we assessed GLUT 4 glucose transporter gene expression in adipocytes from subjects with NIDDM, impaired glucose tolerance (IGT), and obesity. We found that depletion of GLUT 4 transporters and suppression of encoding mRNA constitute a key biochemical mechanism of cellular insulin resistance in these patients.

\section{Methods}

Subjects. The clinical characteristics of the study groups are listed in Table I. The control groups consisted of 11 healthy lean subjects all of whom had a body mass index $\left(\mathrm{BMI}=\right.$ weight $\left.(\mathrm{kg}) / \mathrm{height}\left[\mathrm{m}^{2}\right]\right)$ of $<27$, and 11 healthy obese subjects with BMI ranging from 28.6 to 42.0 . All lean and obese control subjects had normal fasting glucose levels, and the obese individuals were hyperinsulinemic. All obese controls had normal oral glucose tolerance tests (data not shown) by National Diabetes Data Group (28) criteria. We also studied 11 overtly hyperglycemic patients with type II NIDDM, and 4 subjects who were classified as having (IGT) by oral glucose tolerance testing (28). Both these latter subgroups were characterized by basal hyperinsulinemia relative to lean controls $(P<0.05)$, and the mean fasting serum insulin level in subjects with IGT was higher than that in the NIDDM or obese control subgroups $(P<0.2)$. The obese control, NIDDM, and IGT subgroups were well matched for the degree of adiposity; the mean BMI was similar in these three groups $(P=\mathrm{NS})$ and increased over that in lean controls $(P<0.01)$, and the mean adipocyte volume was similar in the obese control and NIDDM subgroups $(P=$ NS).

The mean $( \pm \mathrm{SE})$ duration of disease was $4.2 \pm 1.3 \mathrm{yr}$ in the NIDDM subgroup, including four patients with newly diagnosed diabetes who
Table 1. Clinical Characteristics

\begin{tabular}{|c|c|c|c|c|}
\hline & \multicolumn{2}{|c|}{ Controls } & \multirow[b]{2}{*}{ NIDDM } & \multirow[b]{2}{*}{ IGT } \\
\hline & Lean & Obese & & \\
\hline Number & 11 & 11 & 11 & 4 \\
\hline $\operatorname{Age}(y r)$ & $41 \pm 3$ & $36 \pm 2$ & $47 \pm 3$ & $49 \pm 8$ \\
\hline Gender (M/F) & $11 / 0$ & $9 / 2$ & $11 / 0$ & $4 / 0$ \\
\hline BMI, $\left(\mathrm{kg} / \mathrm{m}^{2}\right)$ & $24 \pm 1$ & $32 \pm 2^{*}$ & $35 \pm 2 *$ & $34 \pm 4^{*}$ \\
\hline $\begin{array}{l}\text { Fasting glucose } \\
\text { (mM) }\end{array}$ & $5.1 \pm 0.1$ & $5.2 \pm 0.2$ & $13.5 \pm 0.8^{*}$ & $5.9 \pm 0.6$ \\
\hline $\begin{array}{l}\text { Fasting insulin } \\
\text { (pM) }\end{array}$ & $61 \pm 13$ & $127 \pm 22^{*}$ & $141 \pm 30^{*}$ & $251 \pm 48^{*}$ \\
\hline $\begin{array}{l}\text { Mean adipocyte size } \\
\text { (pl) }\end{array}$ & $374 \pm 38$ & $1,070 \pm 144^{*}$ & $915 \pm 176^{*}$ & \\
\hline
\end{tabular}

${ }^{*} P<0.05$ relative to lean controls.

had developed hyperglycemic symptoms within 6 mo of study. Of the seven previously diagnosed patients, one was currently being treated with diet alone, and six with insulin. Before the study, however, all diabetic patients were withdrawn from therapy for at least $3 \mathrm{wk}$ and followed on an outpatient basis. All subjects studied were chemically euthyroid, and without renal, hepatic, or cardiac disease. No subject was ingesting pharmacologic agents known to affect carbohydrate homeostasis.

Protocol. After giving informed consent, all subjects were hospitalized on a metabolic ward where they remained active. The subjects were allowed to equilibrate on a weight-maintenance diet (28-32 kcal/ $\mathrm{kg} / \mathrm{day}$ ), consisting of $50 \%$ carbohydrate, $35 \%$ fat, and $15 \%$ protein for 2 d. Standard 75-g oral glucose tolerance tests were then performed. On the next morning, following an overnight fast, $14-45 \mathrm{~g}$ of subcutaneous adipose tissue was obtained by open biopsy of the lower abdominal wall (10). Isolated adipocytes were prepared from each subject by collagenase digestion and glucose transport assays were performed on a small aliquot of these cells. The majority of adipocytes were homogenized for preparation of subcellular membrane fractions and/or disrupted in a guanidinium isothiocyanate solution for extraction of total RNA.

Preparation of adipocytes and glucose transport assays. Adipose tissue was placed immediately into Krebs-Ringer phosphate buffer, $\mathrm{pH}$ 7.4, containing $10 \mathrm{mM}$ Hepes, $2.5 \mathrm{mM} \mathrm{NaH}_{2} \mathrm{PO}_{4}, 4 \% \mathrm{BSA}$ (fraction V; Boehringer Mannheim Biochemicals, Indianapolis, IN), and $5 \mathrm{mM}$ D-glucose. The specimens were brought quickly to the laboratory, trimmed of connective tissue, and weighed. The tissue was minced with fine scissors and isolated adipocytes were obtained by gently shaking the tissue in polypropylene containers at $37^{\circ} \mathrm{C}$ for $1 \mathrm{~h}$ in the same buffer $(0.5 \mathrm{~g} / \mathrm{ml})$ containing $1 \mathrm{mg} / \mathrm{ml}$ collagenase (CooperBiomedical Inc., Freehold, $\mathrm{NJ}$ ), as previously described (10). The adipocytes were then filtered and washed in the Krebs-Ringer phosphate buffer without glucose and collagenase $\left(37^{\circ} \mathrm{C}\right)$, and a small aliquot was removed for immediate cell sizing, counting, and glucose transport assays.

In each subject, the adipocyte diameter of 200 cells was measured using a cell-counting chamber and eyepiece micrometer, and the mean value was used to calculate adipocyte volume, assuming that the cells were spherical. Adipocyte counts were performed according to a modification of method III of Hirsch and Gallian (29), as previously described (30). To measure basal and maximally-stimulated glucose transport rates, cells were incubated in the absence and presence of $100 \mathrm{ng} / \mathrm{ml}$ insulin for $45 \mathrm{~min}$ at $37^{\circ} \mathrm{C}$. Initial rates of 3-0-methylglucose uptake were then assayed by a modification of the method of Whitesell and Gliemann (31) as previously described by Foley et al. (32). In each experiment, glucose transport at each point was the mean of quadruplicate determinations, and the distribution space for radiolabeled 3-0methylglucose in the presence of $0.3 \mathrm{mM}$ phloretin was used to correct 
for nonspecific carryover of radioactivity with cells and the uptake of hexose by simple diffusion.

Analysis of GLUT 4 glucose transporter protein. Isolated adipocytes were homogenized at $17^{\circ} \mathrm{C}$ in a pH 7.4 buffer containing $20 \mathrm{mM}$ Tris$\mathrm{HCl}, 255 \mathrm{mM}$ sucrose, $1 \mathrm{mM}$ EDTA, and protease inhibitors including $5 \mu \mathrm{g} / \mathrm{ml}$ leupeptin, $5 \mu \mathrm{g} / \mathrm{ml}$ pepstatin, and $5 \mu \mathrm{g} / \mathrm{ml}$ aprotinin in a glass homogenizer with a teflon pestle (Arthur $\mathrm{H}$. Thomas Co., Philadelphia, PA). In each subject, a portion of the cell homogenate was used to prepare a postnuclear membrane fraction. The homogenate was first centrifuged at $1,000 \mathrm{~g}$ for $10 \mathrm{~min}$ at $0-2^{\circ} \mathrm{C}$. The postnuclear supernatant was separated from the pellet and fat cake, and then centrifuged at $388,000 \mathrm{~g}$ for $90 \mathrm{~min}$ at $4^{\circ} \mathrm{C}$. The resulting pellet was resuspended in the Tris/sucrose/EDTA buffer (1.5-3.5 $\mathrm{mg}$ protein/ml) and comprised the total cellular membrane fraction.

To study the cellular distribution of glucose transporters, plasma membrane (PM), and low-density microsomal (LDM) and high density microsomal (HDM) membrane subfractions were also prepared from adipocytes using a modification of the differential ultracentrifugation method of McKeel and Jarrett (33). First, equal portions of cells from each subject were incubated $\left(37^{\circ} \mathrm{C}\right)$ in the absence and presence of $100 \mathrm{ng} / \mathrm{ml}$ insulin for $45 \mathrm{~min}$. The adipocytes were then homogenized, and membrane subfractions were obtained from both basal and maximally insulin-stimulated cells $\left(4^{\circ} \mathrm{C}\right)$. The techniques for subfractionation have previously been described in detail (10). Plasma membranes and both microsomal pellets were resuspended in the Tris/sucrose/EDTA buffer ( $1-3 \mathrm{mg}$ protein $/ \mathrm{ml}$ ) and stored frozen at $-70^{\circ} \mathrm{C}$. In the homogenate and membrane fractions, we measured organelle marker enzyme activities including 5'-nucleotidase using the method of Avruch and Wallach (34), uridine $5^{\prime}$-diphosphate-galactose $/ N$-acetylglucosamine galactosyl-transferase using the method of Fleisher (35), and rotenone-insensitive NADH-cytochrome $c$ reductase according to Dallner et al. (36).

For immunoblot analyses, membrane proteins $(75 \mu \mathrm{g})$ were solubilized in Laemmli sample buffer (37) and resolved by SDS-PAGE on $1.5-\mathrm{mm}$ slab gels containing $10 \%$ polyacrylamide. The proteins were then electrophoretically transferred to nitrocellulose filters (38). Immunologic detection of GLUT $\mathbf{4}$ glucose transporters was accomplished as previously described (23). Nitrocellulose filters (Western blots) were incubated with affinity-purified rabbit antiserum (1:100 dilution) specific for the COOH-terminal segment (44 amino acids) of the GLUT 4 transporter cloned from rat skeletal muscle (19), followed by ${ }^{125} \mathrm{I}$-protein A. GLUT 4 transporters were quantitated using autoradiography and scanning densitometry.

Analysis of GLUT 4 glucose transporter $m R N A$. Isolated adipocytes were washed in sterile PBS and total cellular RNA was prepared by guanidinium isothiocyanate $(4 \mathrm{M})$ disruption and centrifugation through $5.7 \mathrm{M}$ cesium chloride (39). After extractions with ethanol, the RNA was dissolved in sterile $\mathrm{H}_{2} \mathrm{O}$, and quantity and purity were assessed by absorbance at 260 and $280 \mathrm{~nm}$. For Northern blot analysis, $20 \mu \mathrm{g}$ total RNA was denatured in $6 \%$ formaldehyde and size-fractionated by electrophoresis on $1 \%$ agarose gels (40). The integrity and relative amounts of RNA were checked by visualization of the ribosomal RNA by shadowing with ultraviolet light. The RNA was then transferred to Nytran membranes (Schleicher \& Schuell, Keene, NH) (41). A near full-length cDNA for the human GLUT 4 glucose transporter (pGEM-4Z/AMT-7) (20) and a 1.1-kb cDNA encoding a constitutive structural protein, CHO-B (42), were ${ }^{32} \mathrm{P}$-labeled to a specific activity of $0.5-1.0 \times 10^{9} \mathrm{cpm} / \mu \mathrm{g}$ by the oligolabeling method (43). cDNA probes for GLUT 4 and CHO-B were kindly made available by Drs. Graeme I. Bell (University of Chicago, Chicago, IL) and Ronald E. Evans (Salk Institute, La Jolla, CA), respectively. These probes were allowed to hybridize to RNA immobilized on the Nytran membranes under high stringency conditions in solutions containing $50 \%$ formamide, $2 \times$ Denhardt's solution, $1 \%$ SDS, and $5 \times \operatorname{SSC}(1 \times$ SSC is $0.15 \mathrm{M} \mathrm{NaCl}, 15$ $\mathrm{mM}$ sodium citrate, $\mathrm{pH} 7)$ at $42^{\circ} \mathrm{C}$. The membranes were then washed in $0.2 \%$ SDS and $0.1 \times \mathrm{SSC}$ at $52^{\circ} \mathrm{C}$, and exposed to Kodak XAR 5 film at $-70^{\circ} \mathrm{C}$ with a Cronex (DuPont Co., Wilmington, DE) intensifying screen. Under these hybridization conditions, the GLUT 4 cDNA binds specifically to its complementary mRNA, and not to mRNAs encoding other members of the GLUT gene family (23). Quantitation was performed by scanning densitometry of the autoradiograms using a laser densitometer.

Other assays and statistics. Plasma glucose was measured by the glucose oxidase method using a glucose analyzer (Beckman Instruments, Inc., Fullerton, CA). Serum insulin levels were measured by radioimmunoassay according to Desbuquois and Aurbach (44). Serum free-insulin levels were measured in diabetic subjects previously treated with insulin as described by Kuzuya et al. (45). Protein was measured by the Coomassie Brilliant Blue method described by Bradford (46) using crystalline BSA as the standard (Bio-Rad protein assay; Bio-Rad Laboratories, Richmond, CA). DNA was quantitated using a spectrofluorometric assay (47). Means are given as means \pm SE and statistical significance was determined using one-way analysis of variance followed by a Fisher protected least significant difference test for pairwise differences. The means and statistical significance reported are based on the untransformed data for ease of interpretation, and are consistent with results obtained from analyses of the data using appropriate variance stabilizing transformations (48).

\section{Results}

Glucose transport activity. In control and NIDDM subjects, we assessed glucose transport activity in vitro using a classic insulin target tissue. Basal and maximally insulin-stimulated rates of 3-O-methylglucose transport were measured in intact adipocytes isolated from lower abdominal wall biopsy specimens in each patient, and mean values for each subject group are shown in Fig. 1. When compared with lean controls, the basal glucose transport rate per cell was unaltered by obesity and NIDDM $(P$ $=$ NS); while basal transport tended to be decreased in NIDDM, the difference was not statistically significant. In contrast, the maximally stimulated glucose transport rate was decreased by $28 \%$ in obese subjects $(P=0.05)$ and by $56 \%$ in NIDDM $(P<0.02)$. Insulin resistance was more profound in NIDDM; maximal glucose transport rates were $39 \%$ less in diabetic subjects compared with the obese control subgroup, and the fold increment over basal was 4.1 in obese and 3.1 in diabetic subjects compared with a value of 5.2 in lean controls. These alterations in glucose transport activity are generally consistent with previously reported results $(3,4,9,10)$.

Cellular content of GLUT 4 glucose transporter protein. We then tested the hypothesis that the decrements in maximally stimulated glucose transport rates were due to decreased expression of the GLUT 4 glucose transporter gene. To test for cellular depletion of GLUT 4 transporter protein, we measured the total number of these carriers in postnuclear membrane fractions using antibodies specific for the $\mathrm{COOH}$-terminal portion of GLUT 4 (19). In each patient, total membrane protein was size-fractionated by polyacrylamide gel electrophoresis, immobilized on nitrocellulose, and reacted with anti-GLUT 4 antibodies followed by ${ }^{125}$ I-protein A; Fig. 2 represents a typical autoradiogram. In all subjects, GLUT 4 migrated as a $\sim 45 \mathrm{kD}$ protein (Fig. $2 \mathrm{~A}$ ). After demonstrating that the intensity of the signal was linearly correlated to the amount of membrane protein loaded on the gel (Fig. 2 B), we quantitated GLUT 4 in total membrane fractions by densitometry. The mean values in each subgroup are shown in Fig. 3. Obesity led to a $40 \%$ reduction $(P<0.03)$ in transporter proteins, and there was even a more marked depletion of $85 \%(P<0.01)$ in NIDDM when expressed per milligram of membrane protein (Fig. $2 A$ ). Using measurements of total membrane protein per cell $(2.6 \pm 1.3 \mathrm{ng}$ in lean, $3.0 \pm 0.7 \mathrm{ng}$ in obese, and $2.9 \pm 1.3 \mathrm{ng}$ in NIDDM sub- 


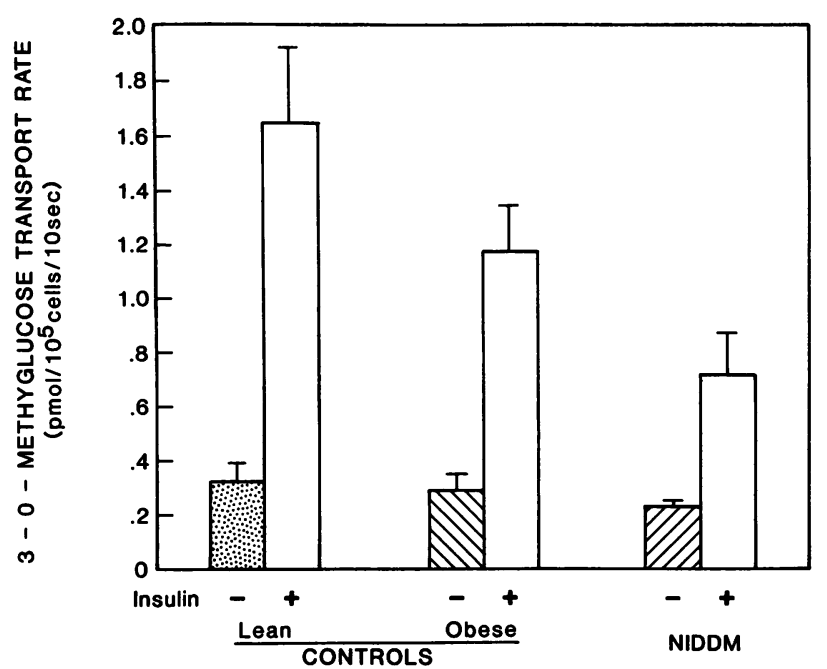

Figure 1. Glucose transport rates in isolated human adipocytes. Adipose tissue was obtained by subcutaneous biopsy from the lower abdominal wall in lean and obese controls and obese NIDDM patients. Isolated adipocytes were prepared, and initial rates of 3-0methylglucose uptake were measured under basal conditions (closed bars) and after acute stimulation with maximal insulin $(100 \mathrm{ng} / \mathrm{ml}$; $30 \mathrm{~min}$ ) (open bars). Data represent the mean $\pm \mathrm{SE}$ of $10-11$ subjects in each subgroup.

groups; $P=\mathrm{NS}$ ), the relative number of GLUT 4 proteins was also normalized per cell in each subject, and the mean data are shown in Fig. $3 \mathrm{~B}$. Thus, the cellular content of GLUT 4 proteins was decreased $42 \%$ in obesity $(P<0.05)$ and $80 \%$ in $\operatorname{NIDDM}(P<0.01)$ compared with lean controls. Immunoblot analysis was performed in one patient with IGT (Fig. $2 A$ ) who was found to have depleted cellular numbers of GLUT 4 transporters in the range of patients with overt diabetes.
Cellular abundance of GLUT 4 glucose transporter $M R N A$. Cellular depletion of GLUT 4 transporters could arise from decreased expression of the encoding mRNA. To test for this possibility, total RNA was prepared from adipocytes isolated from each subject, size-fractionated by agarose gel electrophoresis, and analyzed on RNA blots under conditions for high stringency hybridization with ${ }^{32} \mathrm{P}$-labeled cDNAs encoding GLUT 4 and structural protein CHO-B. As can be seen in Fig. 4, the GLUT 4 cDNA hybridized with a single 3.3-kb mRNA species in both lean and obese controls. GLUT 4 mRNA was detected at low levels in patients with NIDDM and IGT, and is barely discernable in Fig. 4. However, with prolonged exposure, autoradiograms similarly revealed that the size of GLUT 4 mRNA is $3.3 \mathrm{~kb}$ in the glucose-intolerant patients (data not shown).

To better assess the cellular abundance of GLUT 4 mRNA, experiments similar to that depicted in Fig. 4 were performed in multiple subjects within each subgroup, and mRNA was quantitated by densitometric analyses of the autoradiograms. The mean data are shown in Fig. 5, and are expressed in relative units with the mean measurement in lean controls assigned a value of one. In a manner analogous to changes in GLUT 4 protein, the amount of GLUT 4 mRNA was decreased $36 \%(P<0.01)$ in obese subjects relative to lean controls, and even more profoundly by $86 \%(P<0.01)$ in NIDDM, when data were normalized per equal amounts of RNA (Fig. 5 A). Normalization of GLUT 4 mRNA relative to total RNA would not indicate the number of transcripts per cell if diabetes or obesity affected the amount of RNA in adipocytes (23). In our experiments, the amount of RNA recovered per cell was $4.5 \pm 0.7,4.1 \pm 0.6$, and $5.8 \pm 1.8 \mathrm{pg}$ in lean, obese, and diabetic subgroups, respectively $(P=N S)$. These data were used to calculate the amount of GLUT 4 mRNA per cell in each subject (Fig. $5 \mathrm{~B}$ ); normalizing the data in this way did not substantially alter the relative mean levels of GLUT 4 mRNA among the

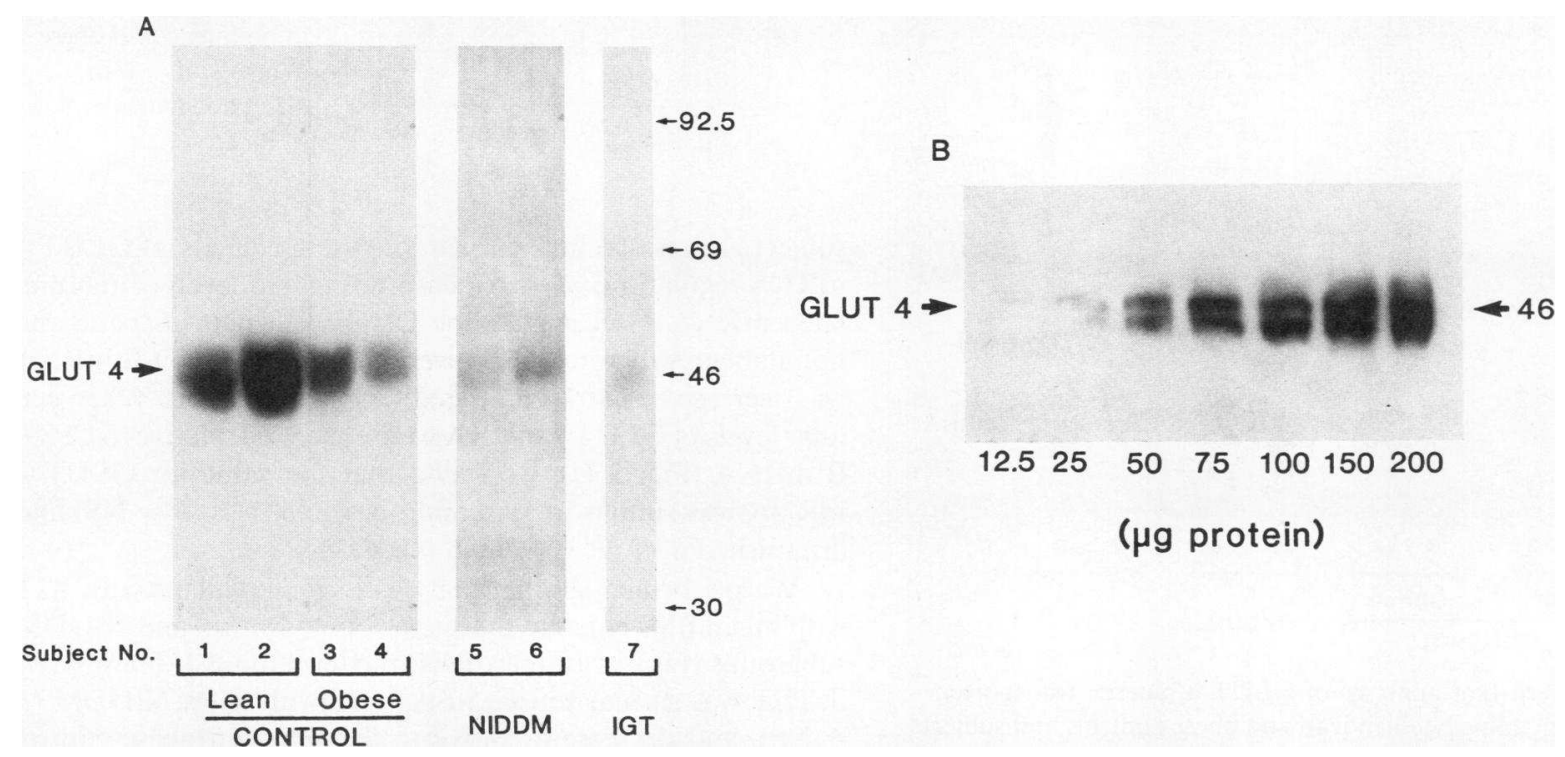

Figure 2. Immunologic identification of GLUT 4 glucose transporters in human adipocytes. $(A)$ Postnuclear total membrane fractions were prepared from adipocytes isolated from lean and obese controls and patients with NIDDM and IGT. Equal amounts of membrane protein (75 $\mu \mathrm{g})$ were resolved by SDS-PAGE, transferred to nitrocellulose, and reacted with polyclonal antibodies specific for the $\mathrm{COOH}$-terminal portion of the GLUT 4 glucose transporter followed by ${ }^{125}$ I-protein A. The figure represents an autoradiogram from a typical experiment. (B) Adipocytes were isolated and pooled from omenta obtained from four patients undergoing elective abdominal surgery. The LDM subfraction was prepared by differential ultracentrifugation (10), and indicated quantities of membrane protein were subjected to Western blot analysis as described for $A$. 


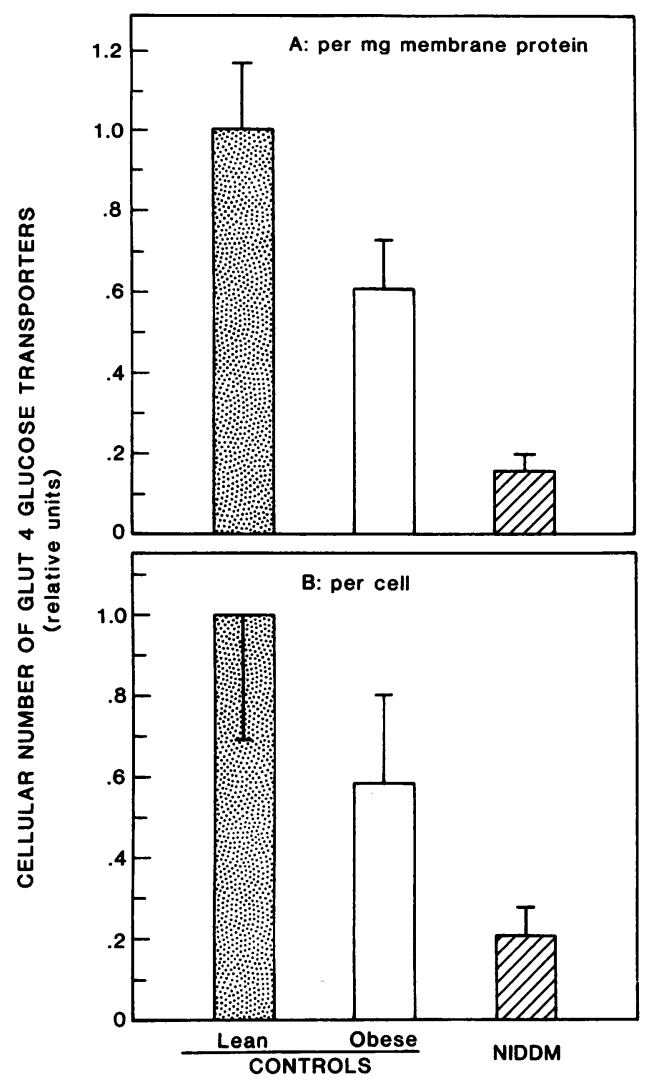

Figure 3. Effects of diabetes mellitus and obesity on the cellular content of GLUT 4 glucose transporters in human adipocytes. Postnuclear total membrane fractions were prepared from isolated adipocytes and analyzed on Western blots using antibodies specific for the GLUT 4 glucose transporter, as described for Fig. 2. GLUT 4 transporters were quantitated on autoradiograms by scanning densitometry, and expressed in each individual as a fraction of the mean value in lean controls. The data represent the mean $\pm \mathrm{SE}$ of $n$ $=4$ in lean controls, $n=7$ in obese controls, and $n=7$ in NIDDM.

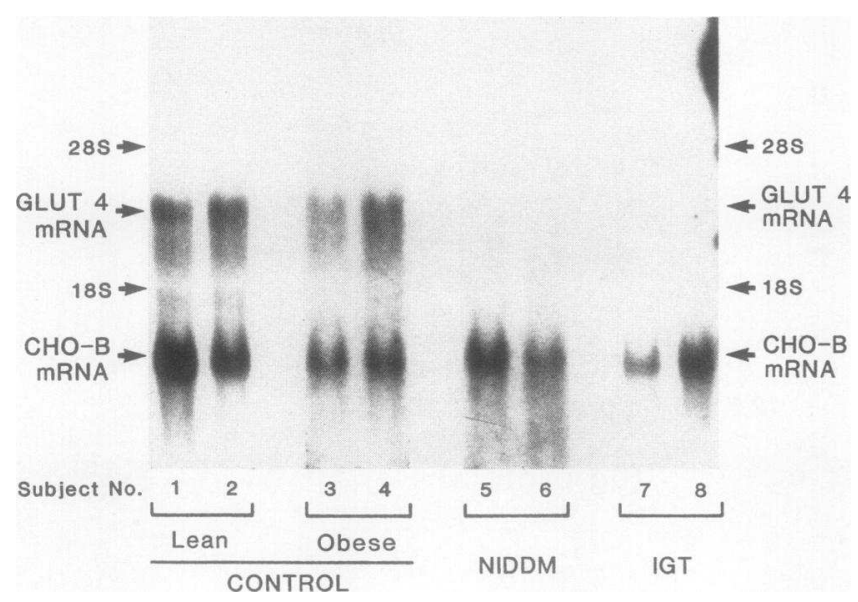

Figure 4. Northern blot analyses of GLUT 4 glucose transporter mRNA in human adipocytes. In lean and obese controls and subjects with NIDDM and IGT, RNA was isolated from adipocytes, sizefractionated $(20 \mu \mathrm{g})$ on $1 \%$ agarose gels, transferred to nylon membranes, and hybridized under high stringency conditions with ${ }^{32}$ P-labeled cDNAs encoding the GLUT 4 glucose transporter (20) and CHO-B protein (42). The figure is an autoradiogram of the Northern blot from a typical experiment. $28 \mathrm{~S}$ and $18 \mathrm{~S}$ indicate migration of the ribosomal subunits.
Figure 5. Effects of diabetes mellitus and obesity on amounts of GLUT 4 glucose transporter mRNA

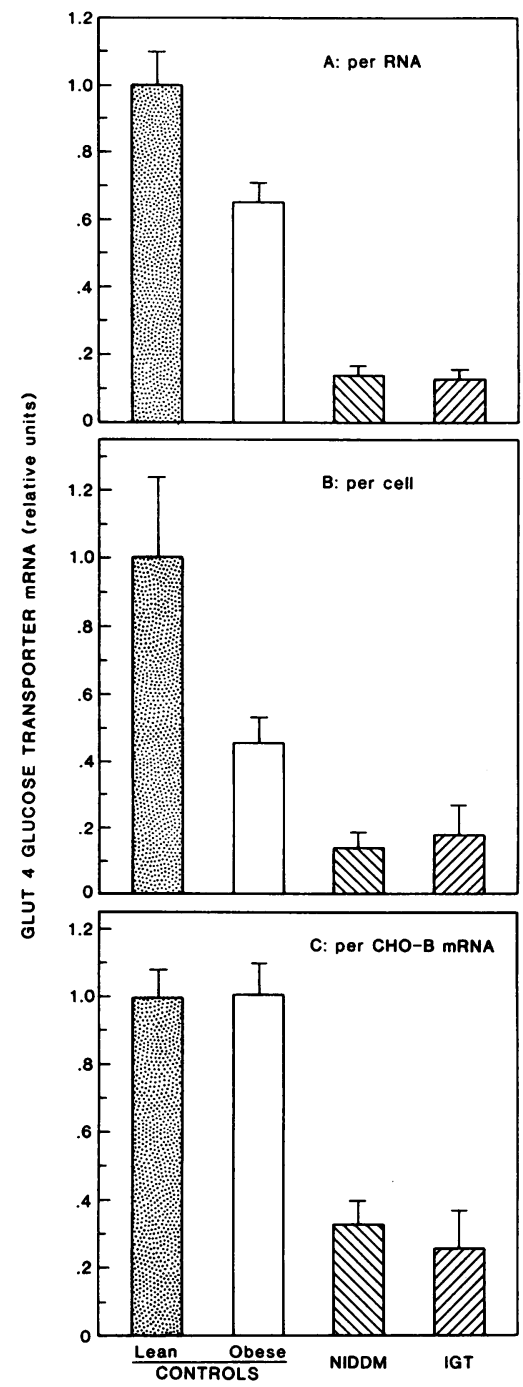
in human adipocytes. RNA was prepared from adipocytes isolated from lean and obese controls and subjects with NIDDM and IGT, and then analyzed on Northern blots as described for Fig. 4. mRNA specifically hybridizing with GLUT 4 glucose transporter and $\mathrm{CHO}$ B cDNAs was quantitated from autoradiograms by scanning densitometry. In each individual, the datum was expressed relative to the mean value in lean controls which was assigned a value of one. The relative amount of GLUT 4 transporter mRNA was normalized as follows: per equal amounts of total RNA in $A$; per cell number in $B$; and for the amount of CHO-B mRNA in $C$. The data represent the mean \pm SE of $n=10$ in both lean and obese controls, $n=9$ in NIDDM, and $n=4$ in IGT.

subject groups. To further examine the specificity of GLUT 4 mRNA regulation, we also measured cellular levels of an unrelated mRNA species encoding CHO-B. In both diabetic and nondiabetic subgroups, the level of adipocyte CHO-B mRNA was decreased $\sim 40 \%$ compared with lean controls. When cellular levels of GLUT 4 mRNA were expressed relative to $\mathrm{CHO}$ B mRNA (Fig. $5 \mathrm{C}$ ), we found that the value for GLUT 4 mRNA was similar in lean and obese controls $(P=\mathrm{NS})$ and diminished $67 \%(P<0.01)$ in NIDDM.

We performed similar analyses in four patients with IGT with mean BMI equal to that in the obese control and NIDDM subgroups (Fig. 5). Interestingly, the level of GLUT 4 mRNA in IGT was similar to that in patients with overt NIDDM $(P$ $=$ NS), and decreased relative to the lean and obese control subgroups $(P<0.01)$, whether expressed per total RNA, per cell, or for the amount of CHO-B mRNA.

Fig. 6 shows the correlation between the levels of GLUT 4 mRNA and the encoded protein in adipocytes from individual subjects. There was a statistically significant correlation $(P$ $<0.02$ ) between these two parameters in nondiabetic control 


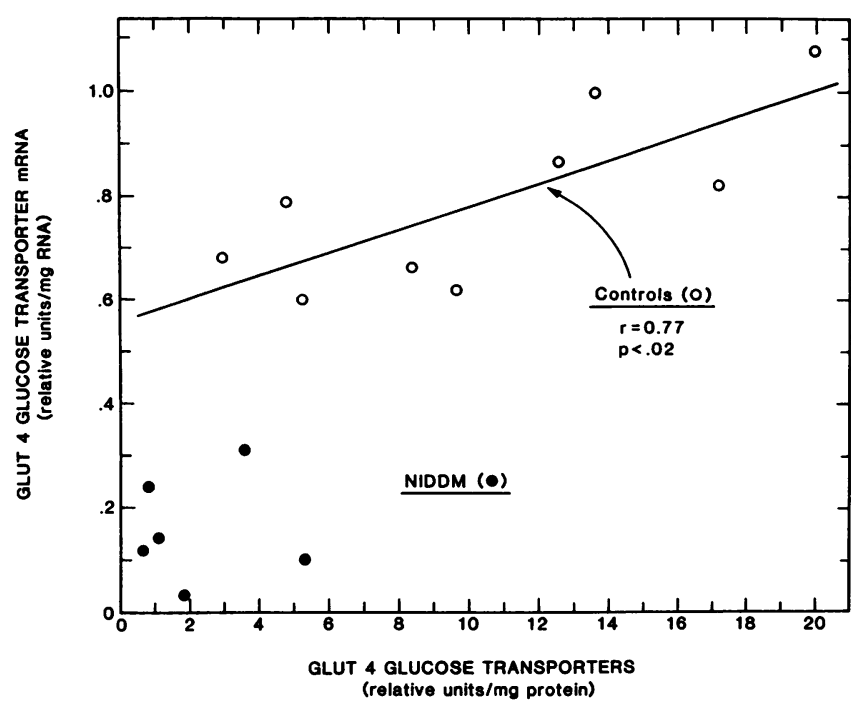

Figure 6. Relationship between the cellular content of GLUT 4 glucose transporters and encoding mRNA in human adipocytes. Adipocytes were isolated from nondiabetic controls over a spectrum of body weight (open circles) and in patients with NIDDM (closed circles). In each subject, GLUT 4 transporter protein was quantitated by Western blot analysis as described for Fig. 3, and the encoding mRNA normalized to total RNA was measured on Northern blots as described for Fig. 5. Linear regression of the discrete data is shown for control subjects only.

subjects over a wide range of BMI $(r=+0.77)$. In contrast, data points in NIDDM patients were clustered in the low range of GLUT 4 mRNA and protein measurements and the values were not significantly correlated $(P=\mathrm{NS})$.
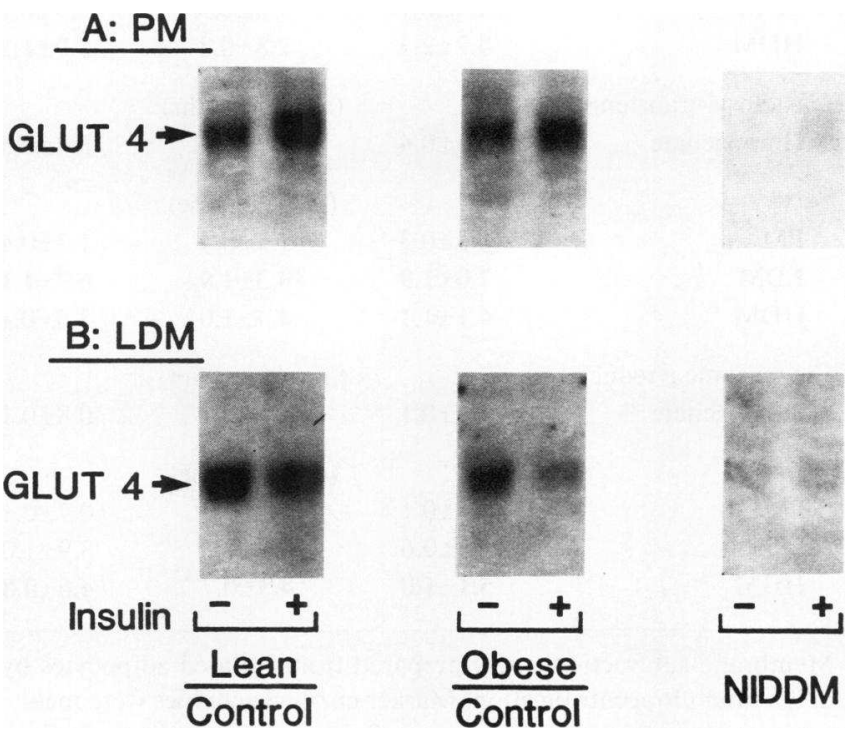

Figure 7. Immunologic identification of GLUT 4 glucose transporters in human adipocyte membrane subfractions: ability of insulin to alter GLUT 4 cellular distribution. Adipocytes were isolated from single lean and obese control subjects and from a patient with NIDDM, and were incubated for $\mathbf{4 5} \mathrm{min}$ in the absence and presence of maximal insulin $(100 \mathrm{ng} / \mathrm{ml})$. The cells were homogenized, and PM $(A)$ and LDM $(B)$ subfractions were prepared using differential ultracentrifugation. Membrane proteins ( $75 \mu \mathrm{g}$ ) were resolved by SDS-PAGE, transferred to nitrocellulose, and reacted with antibodies specific for GLUT 4 followed by protein A. The figure represents an autoradiogram from a single experiment.
Cellular distribution of GLUT 4 glucose transporter protein. Decreased expression of GLUT 4 could only lower glucose transport activity if cellular depletion involved the plasma membrane pool of glucose carriers. To address this issue, adipocytes from control and diabetic subjects were preincubated in the absence and presence of a maximal insulin concentration, homogenized, and subjected to a differential ultracentrifugation protocol for isolating PM, and LDM and HDM subcellular membrane fractions. The number of GLUT 4 transporters was determined by subjecting membrane proteins in the subfractions to SDS-PAGE and immunoblot analyses similar to that described for the total postnuclear membrane fraction (see Figs. 2 and 3). Thus, we were able to determine the cellular distribution of GLUT 4 in both basal and maximally insulinstimulated cells. Fig. 7 is an autoradiogram showing adipocyte PM and LDM subfractions obtained from a single lean and obese control subject and a patient with NIDDM. It is clear that, in each individual, acute insulin stimulation led to an increase in the number of GLUT 4 transporters in PM and a decrease in LDM, indicative of insulin-mediated translocation of transporters from the cell interior to cell surface.

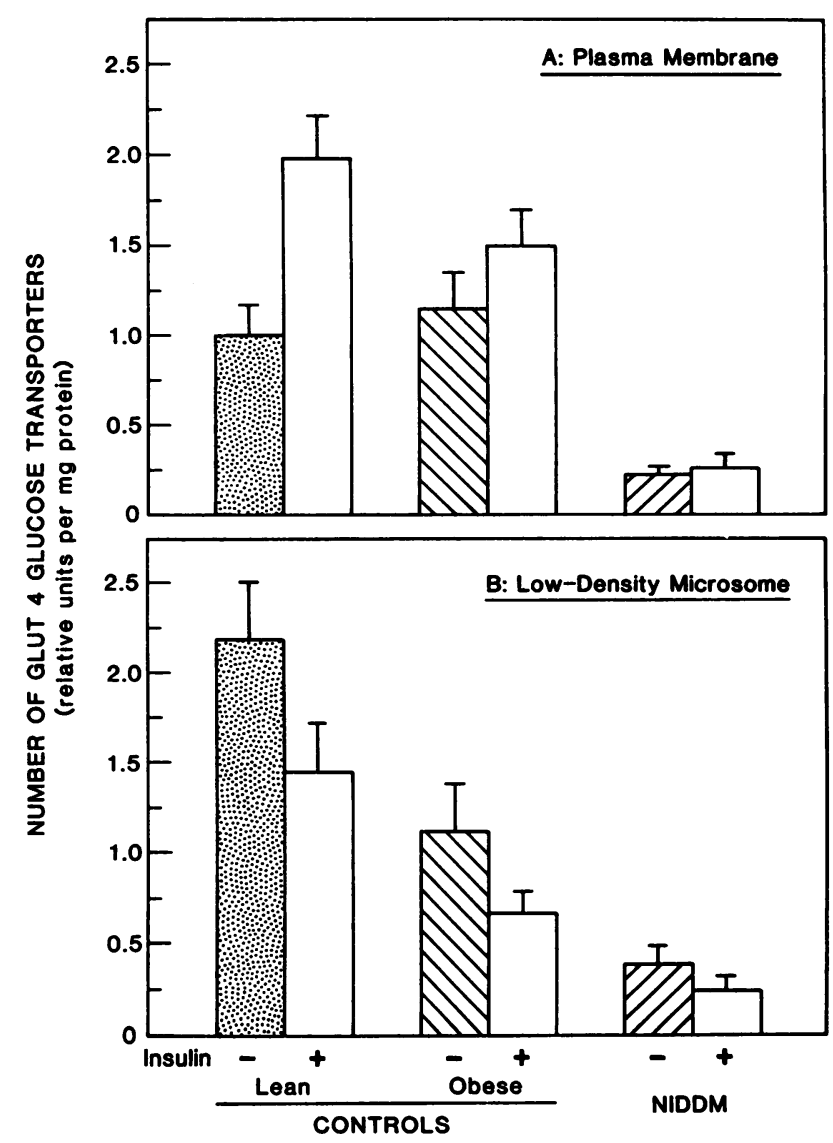

Figure 8. Effects of NIDDM and obesity on GLUT 4 glucose transporters in adipocyte membrane subfractions. Adipocytes were isolated from lean, obese, and NIDDM subjects, incubated in the absence and presence of insulin $(100 \mathrm{ng} / \mathrm{ml})$, and subjected to differential ultracentrifugation for preparation of PM and LDM subfractions. Membrane proteins were subjected to immunoblot analysis using antibodies specific for GLUT 4 as described for Fig. 7, and GLUT 4 was quantitated using autoradiography and densitometry. The data represent the mean \pm SE of $n=8$ in lean controls, $n=6$ in obese controls, and $n=7$ in NIDDM. 


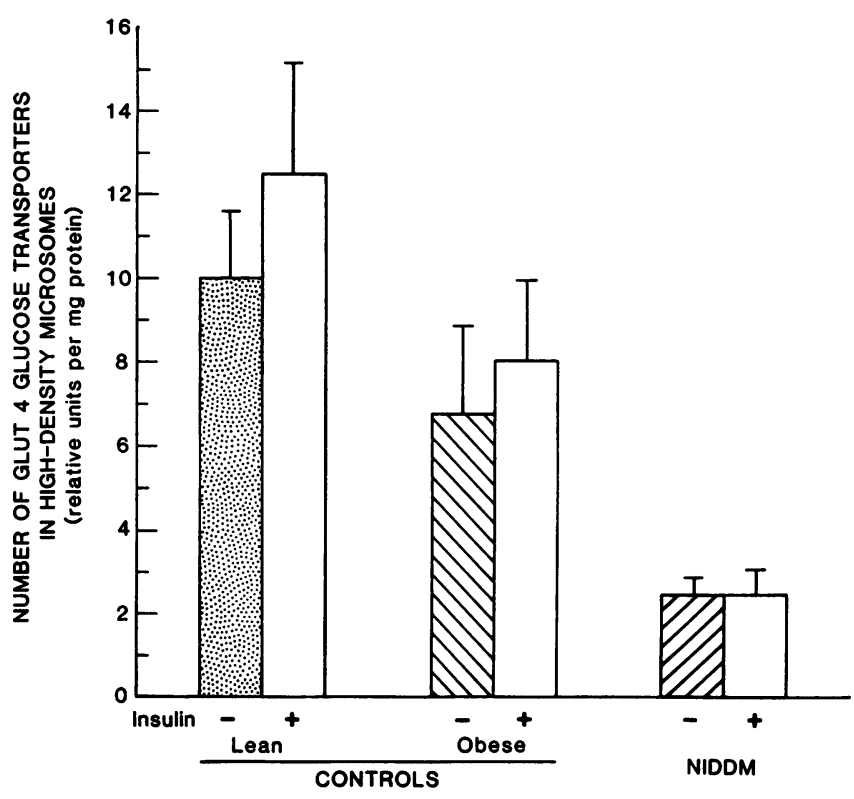

Figure 9. Effects of NIDDM and obesity on GLUT 4 glucose transporters in the HDM subfraction of adipocytes. Adipocytes were isolated from lean, obese, and NIDDM subjects, incubated in the absence and presence of insulin $(100 \mathrm{ng} / \mathrm{ml})$, and subjected to differential ultracentrifugation for preparation of HDM. Membrane proteins were subjected to immunoblot analysis using antibodies specific for GLUT 4 as described for Fig. 7, and GLUT 4 was quantitated using autoradiography and densitometry. Each bar represents the mean $\pm \mathrm{SE}$ of measurements in four subjects.

Among these individuals (Fig. 7), there were obvious quantitative differences in GLUT 4 within each of the membrane subfractions. Therefore, additional subjects were studied, and the mean data for all subgroups are shown in Fig. 8. In basal cells, PM GLUT 4 transporters (per milligram protein) were unchanged $(P=\mathrm{NS})$ in obesity but were reduced $78 \%$ in NIDDM $(P<0.01)$ when compared with lean controls. In LDM, however, obesity per se was associated with a $50 \%$ reduction in GLUT $4(P<0.05)$, and NIDDM led to an even more profound decrement of $82 \%$ compared with lean controls ( $P$ $<0.01)$. When the equally overweight NIDDM and obese control subgroups were directly compared, LDM GLUT 4 transporters were decreased by $65 \%$ in NIDDM $(P<0.01)$. In maximally insulin-stimulated cells, PM GLUT 4 transporters were decreased by $26 \%$ in obesity ( $P=$ NS) and by $87 \%$ in NIDDM $(P<0.01)$, and LDM transporters decreased by $53 \%$ in obesity $(P<0.05)$ and by $83 \%$ in NIDDM $(P<0.01)$, when compared with lean controls. Again, when the obese subgroups were directly compared, NIDDM patients had fewer GLUT 4 in both PM (82\%) and LDM (64\%) relative to their nondiabetic counterparts $(P<0.05)$. The fold-increase over basal in PM GLUT 4 as a result of acute insulin stimulation was 2.0 in lean, 1.4 in obese, and 1.1 in NIDDM subjects.

We also assessed numbers of GLUT 4 transporters in HDM, and the mean data are shown in Fig. 9. It was evident in all subject groups that insulin stimulation did not alter HDM GLUT 4 content $(P=N S)$, indicating that this cellular compartment does not contain a translocating pool of GLUT 4 in human adipocytes. However, GLUT 4 transporters were reduced in HDM in both obese and NIDDM subgroups; when relative values from basal and insulin-stimulated cells were con- sidered together, GLUT 4 were decreased by $34 \%$ in obesity and $78 \%$ in NIDDM compared with lean controls $(P<0.05)$.

Major changes in the fractionation of cells and recovery of membrane protein could affect the relative numbers of GLUT 4 transporters among the subject groups. Therefore, we measured marker enzyme activities in the cell homogenate and in each of the membrane subfractions, including 5'-nucleotidase (34) as a marker for PM, galactosyl-transferase (35) for LDM, and rotenone-insensitive cytochrome $c$ reductase (36) for HDM. The data are shown in Table II. Because insulin had no effect on the recovery or specific activities of these enzymes, measurements in basal and insulin-stimulated cells were averaged to obtain values in individual subjects. When each membrane subfraction was compared among the subject groups, all marker enzymes had comparable activities per milligram protein, except that the homogenate and membrane fractions from NIDDM patients had higher 5'-nucleotidase activity as has been previously reported (10). However, the degrees to which 5'-nucleotidase and the other marker enzymes were enriched (over homogenate) in each of the membrane subfractions was comparable among the subject groups. Also, the de-

Table II. Marker Enzyme Specific Activities in Subcellular Membrane Fractions: Fold Increase Over Cell Homogenate

\begin{tabular}{|c|c|c|c|}
\hline & \multicolumn{2}{|c|}{ Controls } & \multirow[b]{2}{*}{ NIDDM } \\
\hline & Lean & Obese & \\
\hline 5'-Nucleotidase & \multicolumn{3}{|c|}{$\mathrm{nmol} / \mathrm{mg} / \mathrm{h}$} \\
\hline \multirow[t]{2}{*}{ Homogenate } & $3.9 \pm 1.6$ & $4.8 \pm 2.3$ & $14.0 \pm 5.1$ \\
\hline & \multicolumn{3}{|c|}{ fold increase } \\
\hline $\mathbf{P M}$ & $7.1 \pm 2.5$ & $7.9 \pm 2.7$ & $8.9 \pm 3.2$ \\
\hline LDM & $1.4 \pm 0.7$ & $1.3 \pm 0.3$ & $2.5 \pm 0.7$ \\
\hline HDM & $4.2 \pm 2.3$ & $2.8 \pm 0.8$ & $5.0 \pm 1.2$ \\
\hline Galactosyl-transferase & \multicolumn{3}{|c|}{ (nmol/mg/2hr) } \\
\hline Homogenate & $3.3 \pm 0.4$ & $2.8 \pm 0.2$ & $3.4 \pm 0.5$ \\
\hline & \multicolumn{3}{|c|}{ (fold increase) } \\
\hline PM & $1.3 \pm 0.3$ & $1.4 \pm 0.4$ & $1.3 \pm 0.4$ \\
\hline LDM & $7.0 \pm 1.9$ & $10.3 \pm 1.9$ & $6.7 \pm 1.1$ \\
\hline HDM & $4.1 \pm 1.1$ & $4.4 \pm 1.0$ & $3.3 \pm 0.1$ \\
\hline Cytochrome $c$ reductase & \multicolumn{3}{|c|}{$(\mu \mathrm{mol} / \mathrm{mg} / \mathrm{min})$} \\
\hline Homogenate & $1.1 \pm 0.1$ & $1.0 \pm 0.3$ & $0.8 \pm 0.1$ \\
\hline & \multicolumn{3}{|c|}{ (fold increase) } \\
\hline PM & $0.5 \pm 0.1$ & $0.5 \pm 0.1$ & $0.7 \pm 0.1$ \\
\hline LDM & $3.6 \pm 0.6$ & $3.9 \pm 1.0$ & $3.9 \pm 1.0$ \\
\hline HDM & $5.1 \pm 1.0$ & $4.3 \pm 0.7$ & $4.6 \pm 0.8$ \\
\hline
\end{tabular}

Membrane subfractions were prepared from isolated adipocytes by differential ultracentrifugation. Marker enzyme activities were measured and normalized to milligrams of membrane protein; including 5 '-nucleotidase (34) as a marker for PM, galactosyl-transferase (35) as a marker for the Golgi apparatus enriched in LDM, and rotenone-insensitive cytochrome $c$ reductase (36) to mark endoplasmic reticulum enriched in DM. Specific marker enzyme activities were determined in duplicate from membrane fractions prepared from basal and insulin-stimulated cells, but these results were averaged since insulin did not alter enzymatic activities or recoveries. Absolute specific activities are shown for the homogenates, and fold-increase over the value in homogenate is shown for each of the subfractions. The data represent the means \pm SE of data obtained from 4 subjects within each study group. 
gree of cross-contamination of marker enzyme activities in the subfractions was generally not affected by obesity or diabetes. We were able to conclude that major changes in subfractionation could not explain altered concentrations of GLUT 4 transporters in these subgroups.

\section{Discussion}

Insulin resistance is a major metabolic characteristic in NIDDM and obesity, and involves decreased activity of the glucose transport system in insulin target tissue $(1-6,9,10)$. In the current studies, we have examined molecular mechanisms underlying insulin resistance in adipocytes. The data indicate that pretranslational suppression of the GLUT 4 glucose transporter isoform can account for a major portion of cellular insulin resistance in both NIDDM and obesity.

In obesity, we (10) and others (9) have previously demonstrated that maximally insulin-stimulated glucose transport rates are deceased in adipocytes, and that this was primarily due to depleted numbers of glucose transport proteins as measured using the cytochalasin B binding assay. The decrement in the maximal glucose transport rate was a consequence of fewer numbers of intracellular transporters available for insulin-mediated translocation to the cell surface. In fact, with progressive degrees of obesity and insulin resistance, the number of transporters in the intracellular pool was inversely correlated to adipocyte size $(9,10)$. However, the cytochalasin B binding assay measures all membrane-associated proteins with the capacity for facilitative glucose transport and does not discriminate between individual species of glucose transporters. In the current study, we specifically examined the role of the GLUT 4 transporter isoform in insulin resistance since this species may mediate the major portion of insulin-stimulated glucose uptake (11, 19-21, 23, 27). Our results indicate that overall transporter depletion in obesity can be explained by selective loss of the GLUT 4 transporter isoform. As a consequence of GLUT 4 depletion in LDM, fewer transporters are available for insulinmediated translocation. Thus, in maximally stimulated adipocytes, glucose transport rates across the plasma membrane, and the number of cytochalasin B binding sites (10) and GLUT 4 transporters in PM, are all decreased $20-30 \%$ when compared with lean controls. Therefore, impaired insulin responsiveness in human obesity can readily be attributed to depleted numbers of cellular GLUT 4 glucose transporters.

In our previous study (10), more severe insulin resistance in adipocytes from NIDDM patients, over that attributable to obesity per se, was associated with a further decrease in the number of total glucose transporters (i.e., cytochalasin B binding sites). We have now specifically assessed insulin-responsive GLUT 4 glucose transporters and found that expression of this transporter isoform is correspondingly reduced in NIDDM. Since GLUT 4 is the predominant species of glucose transporter in human adipocytes (27), depleted numbers of GLUT 4 transporters can completely account for the overall reduction in cytochalasin B binding sites. It is important to emphasize that the decrease in GLUT 4 cannot be totally attributed to the effects of obesity since cellular levels were more profoundly reduced in the diabetic patients when compared with the equally obese nondiabetic control subgroup. Also, cellular depletion of GLUT 4 involved both the PM and LDM compartments in NIDDM unlike obesity where only the intracellular pool of GLUT 4 was reduced (in basal cells). In maximally stimulated cells, glucose transport rates in NIDDM were de- creased by $56 \%$, cytochalasin B binding sites by $50 \%$ in PM (10), and PM GLUT 4 transporters by $87 \%$ compared with lean controls. The decrements in glucose transport activity and cytochalasin $\mathrm{B}$ binding sites may be less marked since these parameters reflect contributions from both GLUT 1 and GLUT 4; thus, the combined data suggest that the number of GLUT 1 transporters may not be altered in NIDDM. The essential point is that profound depletion of GLUT 4, which was evident in both total membranes and in the PM subfraction, can explain the marked degree of cellular insulin resistance present in NIDDM patients.

In studies to determine the mechanism for GLUT 4 depletion, we found that the cellular content of these transporters in obesity was well correlated with the abundance of GLUT 4 mRNA over a wide range of body weight. This observation indicates that GLUT 4 mRNA expression is suppressed with increasing adiposity, and this event could regulate GLUT 4 transporter protein in adipocytes by limiting de novo synthesis. In NIDDM, more severe cellular depletion of GLUT 4 was coupled to a further reduction in the expression of the encoding mRNA, indicating that pretranslational events are also responsible for the additional loss of GLUT 4. The cellular abundance of GLUT 4 mRNA, when normalized for the amount of $\mathrm{CHO}$ B mRNA (which encodes a structural protein), was not decreased in the obese subgroup compared with lean controls, but was diminished by $67 \%$ in NIDDM. Therefore, reduced expression of GLUT 4 mRNA is an intrinsic characteristic of the diabetic state. Our data in HDM further support the conclusion that diminished expression of GLUT 4 mRNA leads to depletion of the encoded protein in obesity and NIDDM since this fraction is enriched with endoplasmic reticulum $(33,35)$, the organelle in which glucose transporters would be synthesized. Future experiments will be needed to determine whether suppression of GLUT 4 mRNA is due to decreased transcription rates for the GLUT 4 gene or to message instability. In any event, pretranslational depletion of GLUT 4 glucose transporters in adipocytes appears to be an important biochemical event which contributes to cellular insulin resistance in both NIDDM and obesity.

Cellular depletion of GLUT 4 would not necessarily lead to decreased glucose transport activity if it involved only the intracellular pool and spared transporters in the PM. For example, since a portion of GLUT 4 remain in LDM even after maximal stimulation, normal insulin-stimulated transport rates could still be maintained by more efficient translocation of transporters to the cell surface. Therefore, it was important to assess the cellular distribution of GLUT 4 . Our data indicated that cellular depletion of GLUT 4 did involve PM, and this event could explain impaired activity of the insulin-responsive glucose transport system in both NIDDM and obesity. It was also apparent that insulin's ability to increase glucose transport rates (over basal) was greater than could be explained by the increment in GLUT 4 transporters appearing in PM (compare Fig. 1 with Fig. $8 A$ ) in all subject groups. In the past, this discrepancy has been interpreted to mean that insulin activates glucose transport, not only by recruiting intracellular transporters to the PM, but also by enhancing the functional activity of PM transporters. This is a viable explanation since recent data have indicated that this dual mechanism of transport stimulation is operative in rat adipocytes (Karnieli, E., M. Armoni, T. P. Hueckstead, W. T. Garvey, and J. M. Olefsky, unpublished data). However, our data should be interpreted cautiously in this regard since other factors could explain the 
discrepancy between PM-associated transporters and transport rates in intact cells; for example, GLUT 4 transporters in intracellular vesicles could cofractionate with PM (and the 5'-nucleotidase enzyme marker) and yet not be exposed to the extracellular space. It is unlikely that the contribution of GLUT 1, which also translocates in response to insulin, could explain the discrepancy since GLUT 1 constitutes a minor portion of total cellular glucose transporters (27).

Several major metabolic defects have been identified that contribute to hyperglycemia in NIDDM including abnormalities in insulin secretion, elevated rates of hepatic glucose production, and peripheral insulin resistance. Which of these abnormalities is primary and which are acquired in the progressive deterioration of glucose tolerance is currently unknown; however, several recent studies have shown that insulin resistance is the earliest defect identified as individuals progress to overt diabetes (49-52). In this context, it is interesting that adipocyte GLUT 4 mRNA levels were decreased in subjects with IGT to the same extent as in patients with overt NIDDM. The clinical syndrome of IGT is characterized by insulin resistance and supernormal circulating insulin concentrations, and is considered a prediabetic state since individuals develop NIDDM at a rate of $1-5 \%$ per year (28). Our results suggest that pretranslational suppression of GLUT 4 transporters could contribute to insulin resistance in IGT and thus, may constitute an early lesion in the development of diabetes. However, in order to be physiologically relevant, lower levels of GLUT 4 mRNA would need to be accompanied by depleted numbers of the encoded protein, and we were only able to measure the cellular content of GLUT 4 transporter protein in one individual with IGT (which was markedly reduced). Also, the biochemical defects that predominate to impair cellular insulin action in this syndrome have not been fully elucidated. Therefore, more studies in greater numbers of patients are needed to test this hypothesis.

While the current studies pertain exclusively to adipose tissue, the full expression of insulin resistance in NIDDM would necessarily involve biochemical defects in skeletal muscle, which is the most important tissue for insulin-mediated glucose uptake in vivo. Recently, discrepant data have been reported for GLUT 4 expression in skeletal muscle. Pedersen et al. (53) carefully studied vastus lateralis muscle biopsy specimens and found that levels of GLUT 4 mRNA and protein were similar in lean, obese, and NIDDM subgroups. However, in rectus abdominus muscle obtained during elective surgery, Elton et al. (54) reported that NIDDM led to suppression of GLUT 4 mRNA compared with lean and obese controls and that GLUT 4 transporter protein was equally decreased in obese and NIDDM patients relative to lean controls. These combined observations suggest that GLUT 4 may be regulated differently in specific muscle groups or in red vs. white muscle fibers. These issues will need to be examined in detail to understand the full expression of insulin resistance in NIDDM patients. However, our studies in adipose tissue are important in themselves for several reasons. Since adipose tissue accounts for $5-20 \%$ of in vivo glucose uptake (55), defects in the adipocyte glucose transport system could account for a similar proportion of overall in vivo insulin resistance (assuming that GLUT 4 depletion in subcutaneous adipocytes is representative of other anatomical fat depots). Given our observations in subjects with impaired glucose tolerance, insulin resistance in adipose tissue could constitute an initial lesion in the evolution of NIDDM independent of any abnormalities in muscle, which, via a cascade of events, subsequently leads to the full complement of metabolic abnormalities. For example, one possible scenario, based on a combination of observations in vivo and in cultured cells (56), is that insulin resistance in adipose tissue leads to compensatory hyperinsulinemia and postprandial hyperglycemia, which further impairs insulin action and initiates a vicious cycle involving induction/exacerbation of insulin resistance in multiple tissues, secretory exhaustion of pancreatic $\beta$ cells, and hyperglycemia. These ideas are, of course, conjectural but illustrate the potential importance of the current results in the context of testable hypotheses.

In summary, pretranslational events specifically suppress gene expression of the GLUT 4 glucose transporter isoform in adipocytes, and this process appears to be a key mechanism of cellular insulin resistance in NIDDM and obesity. In obesity, insulin's reduced ability to stimulate glucose transport is associated with depleted numbers of intracellular GLUT 4 glucose transporters, and the cellular content of these carriers is well correlated with the level of GLUT 4 mRNA over a wide range of body weight. In NIDDM, a greater degree of insulin resistance is due to a more marked suppression of GLUT 4 transporter mRNA and protein than is attributable to obesity per se. Suppression of GLUT $4 \mathrm{mRNA}$ is also observed in adipocytes from subjects with IGT and could constitute an early lesion in the progressive pathogenesis towards overt diabetes.

\section{Acknowledgments}

We thank Dr. Graeme I. Bell for providing us with the GLUT 4 cDNA; Dr. Ron Evans for the CHO-B cDNA; and Carl Langefeld and Siu Hui for assistance with statistical analyses.

This work was supported by research grants DK-38765 and DK39519 from the National Institutes of Health and by the Veterans Administration Research Service.

\section{References}

1. Reaven, G. M., R. Bernstein, B. Davis, and J. M. Olefsky. 1976. Nonketotic diabetes mellitus: insulin deficiency or insulin resistance? Am. J. Med. 60:80-88.

2. Kolterman, O. G., R. S. Gray, J. Griffin, P. Burstein, J. Insel, J. A. Scarlett, and J. M. Olefsky. 1981. Receptor and postreceptor defects contribute to the insulin resistance in non-insulin-dependent diabetes mellitus. J. Clin. Invest. 68:957-969.

3. Ciaraldi, T. P., O. G. Kolterman, J. A. Scarlett, M. Kao, and J. M. Olefsky. 1982. Role of the glucose transport system in the postreceptor defect of non-insulin dependent diabetes mellitus. Diabetes. 31:1016-1022.

4. Kashiwagi, A., M. A. Verso, J. Andrews, B. Vasquez, G. Reaven, and J. E. Foley. 1983. In vitro insulin resistance of human adipocytes isolated from subjects with non-insulin-dependent diabetes mellitus. J. Clin. Invest. 72:12461254.

5. Dohm, G. L., E. B. Tapscott, W. J. Pories, D. J. Dabbs, E. G. Flickinger, D. Meelheim, T. Fushiki, S. M. Atkinson, C. W. Elton, and J. F. Caro. 1988. An in vitro human muscle preparation suitable for metabolic studies: decreased insulin stimulation of glucose transport in muscle from morbidly obese and diabetic subjects. J. Clin. Invest. 82:486-494.

6. Garvey, W. T., and O. G. Kolterman. 1988. Correlation of in vivo and in vitro actions of insulin in obesity and noninsulin-dependent diabetes mellitus: role of the glucose transport system. Diabetes Metab. Rev. 4:543-569.

7. Cushman, S. W., and L. J. Wardzala. 1980. Potential mechanisms of insulin action on glucose transport in the isolated rat adipose cell: apparent translocation of intracellular transport systems to the plasma membrane. J. Biol. Chem. 255:4758-4762.

8. Suzuki, K., and T. Kono. 1980. Evidence that insulin causes translocation of glucose transport activity to the plasma membrane from an intracellular storage site. Proc. Natl. Acad. Sci. USA. 77:2542-2545.

9. Karnieli, E., A. Barzilai, R. Rafaeloff, and M. Armoni. 1986. Distribution of glucose transporters in membrane fractions isolated from human adipose cells: relation to cell size. J. Clin. Invest. 78:1051-1055.

10. Garvey, W. T., T. P. Huecksteadt, S. Matthaei, and J. M. Olefsky. 1988. The role of glucose transporters in the cellular insulin resistance of type II noninsulin-dependent diabetes mellitus. J. Clin. Invest. 81:1528-1536. 
11. Bell, G. I., T. Kayano, J. B. Buse, C. F. Burant, J. Takeda, D. Lin, H. Fukumoto, and S. Seino. 1990. Molecular biology of mammalian glucose transporters. Diabetes Care. 13:198-208.

12. Mueckler, M., C. Caruso, S. A. Baldwin, M. Panico, I. Blench, H. R. Morris, W. J. Allard, G. E. Lienhard, and H. F. Lodish. 1985. Sequence and structure of a human glucose transporter. Science (Wash. DC). 229:941-945.

13. Birnbaum, M. J., H. C. Haspel, and O. M. Rosen. 1986. Cloning and characterization of a cDNA encoding the rat brain glucose transporter protein. Proc. Natl. Acad. Sci. USA. 83:5784-5788.

14. Sarkar, H. K., B. Thorens, H. F. Lodish, and H. R. Kaback. 1988. Expression of the human erythrocyte glucose transporter in Escherichia coli. Proc. Natl. Acad. Sci. USA. 85:5463-5467.

15. DeFronzo, R. A., E. Jacot, E. Jequier, E. Maeder, and J. P. Felber. 1981 The effect of insulin on the disposal of intravenous glucose: results from indirect calorimetry and hepatic and femoral venous catheterization. Diabetes. 30:1000 1007.

16. Fukumoto, H., S. Seino, H. Imura, Y. Seino, R. L. Eddy, Y. Fukushima, M. G. Byers, T. B. Shows, and G. I. Bell. 1988. Sequence, tissue distribution, and chromosomal localization of mRNA encoding a human glucose transporter-like protein. Proc. Natl. Acad. Sci. USA. 85:5434-5438.

17. Thorens, B., H. K. Sarkar, H. R. Kaback, and H. F. Lodish. 1988. Cloning and functional expression in bacteria of a novel glucose transporter present in liver, intestine, kidney, and beta pancreatic islet cells. Cell. 55:281-291.

18. Kayano, T., H. Fukumoto, R. L. Eddy, Y. S. Fan, M. G. Byers, T. B. Shows, and G. I. Bell. 1988. Evidence for a family of human glucose transporterlike proteins. J. Biol. Chem. 263:15245-15248.

19. Birnbaum, M. J. 1989. Identification of a novel gene encoding an insulinresponsive glucose transporter protein. Cell. 57:305-315.

20. Fukumoto, H., T. Kayano, J. B. Buse, Y. Edwards, P. F. Pilch, G. I. Beil, and S. Seino. 1989. Cloning and characterization of the major insulin-responsive glucose transporter expressed in human skeletal muscle and other insulin-responsive tissues. J. Biol. Chem. 264:7776-7779.

21. James, D. E., M. Strube, M. Mueckler. 1989. Molecular cloning and characterization of an insulin-regulatable glucose transporter. Nature (Lond.) 338:83-87.

22. Kaestner, K. H., R. J. Christy, and M. D. Lane. 1990. Mouse insulin-responsive glucose transporter gene: characterization of the gene and trans-activation by the CCAAT/enhancer binding protein. Proc. Natl. Acad. Sci. USA $87: 251-255$.

23. Garvey, W. T., T. P. Huecksteadt, and M. J. Birnbaum. 1989. Pretranslational suppression of an insulin-responsive glucose transporter in rats with diabetes mellitus. Science (Wash. DC). 245:60-63.

24. Berger, J., C. Biswas, P. P. Vicario, H. V. Strout, R. Saperstein, and P. F. Pilch. 1989. Decreased expression of the insulin-responsive glucose transporter in diabetes and fasting. Nature (Lond.). 340:70-72.

25. Sivitz, W. I., S. L. DeSautel, T. Kayano, G. I. Bell, and J. E. Pessin. 1989. Regulation of glucose transporter messenger RNA in insulin-deficient states. $\mathrm{Na}$ ture (Lond.). 340:72-74.

26. Kahn, B. B., M. J. Charron, H. F. Lodish, S. W. Cushman, and J. S. Flier. 1989. Differential regulation of two glucose transporters in adipose cells from diabetic and insulin-treated diabetic rats. J. Clin. Invest. 84:404-411.

27. Pilch, P. F., W. Wilkinson, W. T. Garvey, T. P. Ciaraldi, T. P. Huecksteadt, and J. M. Olefsky. 1991. Insulin responsive human adipocytes express two glucose transporter isoforms and target them to different vesicles. J. Clin. Endocrinol. Metab. In press.

28. National Diabetes Data Group. 1979. Classification and diagnosis of diabetes mellitus and other categories of glucose intolerance. Diabetes. 28:10391057.

29. Hirsch, J., and E. Gallian. 1968. Methods for the determination of adipose cell size in man and animals. J. Lipid Res. 9:110-119.

30. Marshall, S., W. T. Garvey, and M. Geller. 1984. Primary culture of isolated adipocytes: a new model to study insulin receptor regulation and insulin action. J. Biol. Chem. 259:6376-6384

31. Whitesell, R. R., and J. Gliemann. 1979. Kinetic parameters of transport of 3-O-methylglucose and glucose in adipocytes. J. Biol. Chem. 254:5276-5283.

32. Foley, J. E., R. Foley, and J. Gliemann. 1980. Rate-limiting steps of 2-deoxyglucose uptake in rat adipocytes. Biochim. Biophys. Acta. 599:689-698.

33. McKeel, D. W., and L. Jarrett. 1970. Preparation and characterization of a plasma membrane fraction from isolated fat cells. J. Cell Biol. 44:417-438.

34. Avruch, J., and D. F. H. Wallach. 1971. Preparation and properties of plasma membrane and endoplasmic reticulum fragments from isolated rat fat cells. Biochim. Biophys. Acta. 233:334-347.

35. Fleisher, B. 1974. Isolation and characterization of Golgi apparatus and membranes from rat liver. Methods Enzymol. 31:180-191.

36. Dallner, G., P. Siekevitz, and G. E. Palade. 1966. Biogenesis of endoplasmic reticulum membranes. J. Cell Biol. 30:97-117.

37. Laemmli, U. K. 1970. Cleavage of structural proteins during the assembly of the head of bacteriophage T4. Nature (Lond.). 227:680-685.

38. Towbin, H., T. Staehelin, and J. Gordon. 1979. Electrophoretic transfer of proteins from polyacrylamide gels to nitrocellulose sheets: procedure and some applications. Proc. Natl. Acad. Sci. USA. 76:4350-4354.

39. Chirgwin, J. W., A. E. Przybyla, R. J. MacDonald, and W. J. Rutter. 1979. Isolation of biologically active ribonucleic acid from sources enriched in ribonuclease. Biochemistry. 18:5294-5299.

40. Thomas, P. S. 1980. Hybridization of denatured RNA and small DNA fragments transferred to nitrocellulose. Proc. Natl. Acad. Sci. USA. 77:52015205.

41. Southern, E. M. 1975. Detection of specific sequences among DNA fragments separated by gel electrophoresis. J. Mol. Biol. 98:503-517.

42. Harpold, M. M., R. M. Evans, M. Salditt-Georgieff, and J. E. Darnell. 1979. Production of mRNA in chinese hamster cells: relationship of the rate of synthesis to the cytoplasmic concentration of nine specific mRNA sequences. Cell. 17:1023-1035.

43. Feinberg, A., and B. Vogelstein. 1984. A technique for radiolabeling DNA restriction endonuclease fragments to high specific activity. Anal. Biochem. 137:266-273.

44. Desbuquois, B., and G. D. Aurbach. 1971. Use of polyethylene glycol to separate free and antibody-bound peptide hormones in radio-immunoassays. $J$. Clin. Endocrinol. Metab. 33:732-738.

45. Kuzuya, H., P. M. Blix, D. L. Horowitz, D. L. Steiner, and A. H. Rubenstein. 1977. Determination of free and total insulin and C-peptide in insulintreated diabetics. Diabetes. 26:22-29.

46. Bradford, M. 1976. A rapid and sensitive method for the quantitation of microgram quantities of protein utilizing the principle protein-dye bonding. Anal. Biochem. 72:248-254.

47. Labarca, C., and K. Paigen. 1980. A simple, rapid, and sensitive DNA assay procedure. Anal. Biochem. 102:344-352.

48. Steel, R. G. D., and J. H. Torrie. 1980. Analysis of variance II: multiway classifications. In Principles and Procedures of Statistics: a Biometrical Approach. McGraw-Hill, New York. 233-236.

49. Lillioja, S., D. M. Mott, B. V. Howard, P. H. Bennett, H. Yki-Jarvinen, D. Freymond, B. L. Nyomba, F. Zurlo, B. Swinburn, and C. Bogardus. 1988. Impaired glucose tolerance as a disorder of insulin action: longitudinal and crosssectional studies in Pima Indians. N. Engl. J. Med. 318:1217-1224.

50. Lillioja, S., D. M. Mott, J. K. Zawadzki, A. A. Young, W. G. H. Abbott, W. C. Knowler, P. H. Bennett, P. Mall, and C. Bogardus. 1987. In vivo insulin action is familial characteristic in nondiabetic Pima Indians. Diabetes. 36:13291335.

51. Hansen, B. C., and N. L. Bodkin. 1986. Heterogeneity of insulin responses: phases leading to type 2 (non-insulin-dependent) diabetes mellitus in the rhesus monkey. Diabetologia. 29:713-719.

52. Warram, J. H., B. C. Martin, J. S. Soeldner, and A. S. Krolewski. 1988. Study of glucose removal rate and first phase insulin secretion in the offspring of two parents with non-insulin-dependent diabetes. In Prediabetes. R. A. Camerini-Davalos and H. S. Cole, editors. Plenum Press, New York and London. 175183.

53. Pedersen, O., J. F. Bak, P. H. Andersen, S. Lund, D. E. Moller, J. S. Flier, and B. B. Kahn. 1990. Evidence against altered expression of GLUT 1 or GLUT 4 in skeletal muscle of patients with obesity or NIDDM. Diabetes. 39:865-870.

54. Elton, C. W., L. Roy, D. E. Moller, P. F. Pilch, W. J. Pories, S. M. Atkinson, and G. L. Dohm. 1990. Decreased expression of an insulin-sensitive glucose transporter in muscle from insulin-resistant obese and diabetic patients. Diabetes. 39(Suppl. 1):120A. (Abstr.)

55. Marin, P., M. Rebuffë-Scrive, U. Smith, and P. Bjorntorp. 1987. Glucose uptake in human adipose tissue. Metabolism. 36:1154-1160.

56. Garvey, W. T. Pathogenesis and cellular mechanisms of insulin resistance in type II non-insulin-dependent diabetes mellitus. 1988. In Pathogenesis of NonInsulin Dependent Diabetes. V. Grill and S. Efendic, editors. Raven Press, New York. 171-200. 